\title{
Wharton's jelly cells from sheep umbilical cord maintained with different culture media are permissive to in vitro infection by Small Ruminant Lentiviruses
}

\author{
[Células da geleia de Wharton do cordão umbilical ovino mantidas em diferentes meios de cultivo são \\ permissivas à infecção in vitro por lentivírus de pequenos ruminantes] \\ R.P. Dias ${ }^{1}$, R.R. Pinheiro ${ }^{2}$, A. Andrioli ${ }^{2}$, A.C. Farias $^{3}$, A.L.M. Sousa ${ }^{4}$, D.A.A. Azevedo ${ }^{1}$, \\ J.F. Araújo ${ }^{4}$, T.D. F. Aguiar ${ }^{1,5}$, M.F.S. Teixeira ${ }^{1,6}$ \\ ${ }^{1}$ Universidade Estadual do Ceará - Fortaleza, CE \\ ${ }^{2}$ Embrapa Caprinos e Ovinos - Sobral, CE \\ ${ }^{3}$ Faculdades Integradas do Tapajós - Santarém, PA \\ ${ }^{4}$ Universidade Estadual Vale do Acaraú - Sobral, CE \\ ${ }^{5}$ Bolsista de Pós Doutorado Funcap/CAPES \\ ${ }^{6}$ Bolsista de Produtividade em Pesquisa do CNPq
}

\begin{abstract}
This study aimed to isolate cells from the Wharton's jelly of umbilical cord (WJUC) of sheep collected during natural parturition using different culture media, in addition to reporting for the first time the permissiveness of these cells to in vitro infection by small ruminant lentiviruses. Ten umbilical cords were collected from healthy sheep. Each cord explants were grown in different media consisting of MEM, low glucose DMEM, M199, and RPMI-1640. The permissiveness of infection of sheep cells from WJUC was tested with CAEV-Cork and MVV-K1514 strains, inoculating $0.1 \mathrm{MOI}$ of each viral strain. Four supernatants from each strain were obtained from WJUC sheep cell cultures infected in different media. The results demonstrated the presence of cytopathic effect after the in vitro infection by CAEV-Cork and MVV-K1514 with all of the tested culture media. Nested-PCR detected proviral DNA in all supernatants. Supernatants containing CAEV-Cork viruses had TCID $_{50} / \mathrm{ml}$ titres of $10^{5.5}$ in MEM, $10^{4.0}$ in low glucose DMEM, $10^{5.0}$ in M199, and $10^{5.7}$ in RPMI-1640. Supernatants containing the MVV-K1514 virus had TCID $_{50} / \mathrm{ml}$ titres of $10^{4.3}$ in MEM, $10^{3.5}$ in low-glucose DMEM, $10^{4.7}$ in M199, and $10^{3.5}$ in RPMI-1640. Sheep cells from WJUC are permissive to in vitro infection by small ruminant lentivirus.
\end{abstract}

Keywords: CAEV-Cork, MVV-K1514, permissiveness, in vitro infection

\section{RESUMO}

O objetivo deste estudo foi isolar células da geleia de Wharton do cordão umbilical (GWCU) ovino coletado por ocasião do parto natural, utilizando-se diferentes meios de cultivo, além de relatar, pela primeira vez, sua permissividade à infecção in vitro por lentivírus de pequenos ruminantes (LVPRs). Dez cordões umbilicais foram coletados de ovelhas hígidas e soronegativas para LVPRs pelo teste de imunodifusão em gel de agarose (IDGA). De cada cordão, explantes foram cultivados em quatro meios distintos que consistiram em MEM, DMEM baixa glicose, meio 199 e RPMI-1640, todos acrescidos de 10\% de soro fetal bovino em estufa com atmosfera úmida e $5 \%$ de $\mathrm{CO}_{2}$ a $37^{\circ} \mathrm{C}$. A permissividade de infecção das células GWCU ovino foi testada frente às cepas CAEV-Cork e MVV-K1514, inoculando-se 0,1 MOI de cada cepa viral e corando as monocamadas com May Grunwald Giemsa para visualização do efeito citopático. Foram obtidos quatro sobrenadantes CAEV-Cork e quatro MVV-K1514, provenientes do cultivo de células GWCU ovino infectadas por 21 dias em meios distintos, dos quais foram realizadas titulação em membrana sinovial caprina e extração do DNA próviral para realização de nested-PCR e eletroforese em gel de agarose a $2 \%$. Os resultados demonstraram a presença de efeito citopático na infecção in vitro tanto por CAEV-Cork como por MVV-K1514 em todos os meios de cultivo, sendo visualizados sincícios e lise celular em microscópio invertido. A nested-PCR detectou o DNA pró-viral tanto do CAEV-Cork como do MVV-K1514 em todos os sobrenadantes. Os sobrenadantes contendo o vírus CAEV-Cork apresentaram títulos em TCID ${ }_{50} / \mathrm{mL}$ de $10^{5,5}$ em MEM, $10^{4,0}$ em DMEM baixa

Recebido em 10 de março de 2016

Aceito em 13 de junho de 2016

E-mail: ronaldodias01@yahoo.com.br 
glicose, $10^{5,0}$ em meio 199 e 10,7 em RPMI-1640. Os sobrenadantes contendo o vírus MVV-K1514 apresentaram título em TCID ${ }_{50} / \mathrm{mL}$ de $10^{4,3} \mathrm{em} \mathrm{MEM,} 10^{3,5}$ em DMEM baixa glicose, $10^{4,7}$ em meio 199 e $10^{3,5}$ em RPMI-1640. Células GWCU ovino são permissivas à infecção in vitro pelos lentivírus de pequenos ruminantes CAEV-Cork e MVV-K1514.

Palavras-chave: CAEV-Cork, MVV-K1514, permissividade, infecção in vitro

\section{INTRODUCTION}

SRLV are a group of highly heterogenic viruses capable of infecting sheep and goats, causing different clinical manifestations depending on the virulence of the strain involved. In order to control these infections and avoid their consequences in flocks, periodically performing serologic diagnostics are necessary, using essays with adequate specificity spectrum to identify seropositive animals (Minguijón et al., 2015).

In order to do so, the in vitro production of viral proteins is essential due to their use in indirect diagnostic tests. Conventionally, this production is performed with viral replication in permissive cells, which are most frequently extracted from goat synovial membrane (GSM) and choroid plexus, and used to replicate caprine arthritis encephalitis virus (CAEV), and Maedi-Visna virus (MVV), respectively (Caprine..., 2008). However, these tissues are usually collected from fetuses or neonates, which are then euthanized to obtain cells with a higher potential for in vitro growth.

In this context, using umbilical cord tissue is an alternative that provides cells without harming ethical principles or causing unnecessary suffering in animals, in addition to being an easy source to obtain these cells with an elevated capacity for in vitro proliferation (Vita et al., 2012).

Umbilical cord forms a bond between placenta and fetus. It contains a vein and two arteries surrounded by the Wharton's Jelly (WJ), which are covered by a simple amniotic epithelium. WJ is formed by a mucosal connective tissue composed by mesenchymal cells immersed in a basal substance (Ba'nkowski et al., 1993).

These cells have elevated potential for many applications and, therefore generated great interest in the genic and cellular therapies, cloning, biotechnological and viral studies (Cardoso et al., 2012a). The permissiveness to infection by bovine herpesvirus type 5 have already been demonstrated in cells collected from bovine WJUC (Cardoso et al., 2012b).

Therefore, this study aimed to isolate sheep cells from Wharton's jelly of umbilical cords (WJUC) collected at natural parturition using different culture media in isolation and maintenance, in addition to first report the permissiveness of these cells to in vitro infection by SRLV.

\section{MATERIAL AND METHODS}

The experiment was submitted and approved by the local Ethics Committee for the Use of Animals (CEUA) of the State University of Ceará (UECE) with the following protocol number 12776979-0.

Umbilical cords $(n=10)$ were collected from healthy mixed breed sheep from two farms located in Guaiuba city, Ceará State. The animals tested negative for SRLVs by agar gel immunodiffusion test (AGID), using a commercial kit (MVV-AGID, Biovetech $\AA$, Brasil) that detects anti-p28 antibodies in ovine serum. At natural parturition, umbilical cords were pinched with sterile hemostatic scissors and cut into sections of 6 to $10 \mathrm{~cm}$. Once collected, each cord was washed with sterile PBS added $2 \%$ penicillin and streptomycin $(\mathrm{P} / \mathrm{S})\left(\mathrm{Gibco}^{\mathrm{TM}}\right.$, California) to remove the excess of blood and to disinfect, then placed in $50 \mathrm{~mL}$ falcon tubes immersed in low glucose DMEM added with 4\% $\mathrm{P} / \mathrm{S}$ and 1\% amphotericin B (Cristália - Produtos Químicos Farmacêuticos Ltda., Brasil).

Tubes were placed in isothermal boxes with recyclable ice $\left(4^{\circ} \mathrm{C}\right)$ and sent for processing at the Virology Laboratory, State University of Ceará.

Explants from sheep WJUC were cultured in 6well plates (Kasvi, Brasil) in four distinct media, which were: MEM, low glucose DMEM, medium 199 (M199), and RPMI-1640 (Gibco ${ }^{\mathrm{TM}}$, California). To all of these media $10 \%$ fetal 
bovine serum (FBS) $\left(\mathrm{Gibco}^{\mathrm{TM}}\right.$, California), 2\% $\mathrm{P} / \mathrm{S}$, and $1 \%$ amphotericin $\mathrm{B}$ were added and plates were maintained in an incubator with humid atmosphere with $5 \% \quad \mathrm{CO}_{2}$ at $37^{\circ} \mathrm{C}$. When monolayers reached $80 \%$ confluence, trypsinization was performed in bottles of $75 \mathrm{~cm}^{2}$ (Kasvi, Brasil) and the respective medium was replaced every 2 to 3 days.

Permissiveness of sheep cells from WJUC to infection was tested with two SRLVs strains in 6-well plates, in which two wells were inoculated with CAEV-Cork, two with MVV-K1514 and the remaining two were not inoculated, used as negative control for each medium (MEM, low glucose DMEM, M199 or RPMI-1640). The inoculation was performed in monolayers with $90 \%$ confluence, which were washed twice with PBS to remove FBS and added $1 \mathrm{~mL}$ of the respective medium, free of serum, containing 0.1 MOI $(100 \mu \mathrm{L}$ of viral supernatant) as an inoculum of each strain and incubated for viral adsorption in humid atmosphere with $5 \% \mathrm{CO}_{2}$ at $37^{\circ} \mathrm{C}$ for one hour. Then, monolayers were washed with PBS and incubated with the respective medium, added $2 \% \mathrm{FBS}, 2 \% \mathrm{P} / \mathrm{S}$, and $1 \%$ amphotericin $\mathrm{B}$. At the end of seven days, the medium was removed from wells, which were then stained with May Grunwald Giemsa and cytopathic effect was visualized with inverted microscope Olympus CKX41 coupled with camera Olympus Evolt E-330.

Supernatants containing viral particles were produced in $150 \mathrm{~cm}^{2}$ bottles (Corning, USA) containing monolayers of WJUC-derived sheep cells, inoculated with viral suspension to assess replication of CAEV-Cork and MVV-K1514 in different culture media. When monolayers reached $90 \%$ confluence, the medium was removed and two washings were performed with PBS to remove FBS from layers. Then, $15 \mathrm{~mL}$ of inoculum composed of medium free of FBS and added $200 \mu \mathrm{L}$ of viral suspension containing CAEV-Cork or MVV-K1514 strain was added for one hour in humid atmosphere with $5 \% \mathrm{CO}_{2}$ at $37^{\circ} \mathrm{C}$. After this period, the inoculum was replaced by $40 \mathrm{~mL}$ of medium (MEM, low glucose DMEM, M199, or RPMI-1640) containing $2 \%$ FBS, $2 \% \quad \mathrm{P} / \mathrm{S}$, and $1 \%$ amphotericin B. Every seven days, supernatants were collected and each medium was replaced by the same concentrations of FBS, $\mathrm{P} / \mathrm{S}$ and amphotericin $\mathrm{B}$ as previously mentioned.
Therefore, three collections in a 21 day period were performed in which all bottles were frozen and de-frozen at the third collection for cellular lysis and liberation of viral particles. With this methodology, eight supernatants were obtained, which were four CAEV-Cork and four MVV$\mathrm{K} 1514$, each with a distinct medium.

Titration of the eight supernatants containing replicated viral particles in WJUC-derived sheep cells was performed with 10 serial dilutions and four wells for each dilution in 96-well plates (Corning, USA) containing monolayers of GSM cells. Supernatants of CAEV-Cork and MVVK1514 replicated in GSM were used as standard. Viral titers were calculated according to Reed and Muench (1938) as the highest dilution that after 14 days post inoculation presented syncytia in $50 \%$ of inoculated wells and was expressed as the $50 \%$ Tissue Culture Infective Dose $\left(\mathrm{TCID}_{50}\right)$ by $\mathrm{mL}$ of supernatant.

Supernatants were used to extract proviral DNA and PBS $1 \mathrm{X}$ in 1:1 was used to centrifuge $4 \mathrm{~mL}$ of each supernatant at $250 \mathrm{~g}$ for 5 minutes. Then, superior phase was discarded and the pellet was washed again in PBS in the same previous conditions. The pellet was then resuspended in $2 \mathrm{~mL}$ of hypertonic buffer for two minutes at room temperature for lysis of cellular cytoplasm, after which centrifugation at $1,100 \mathrm{~g}$ for 10 minutes was performed. The pellet was resuspended in $2 \mathrm{~mL}$ of $\mathrm{PBS}$ and centrifuged at $1,100 \mathrm{~g}$ for 10 minutes. Then, sediment was resuspended in $250 \mathrm{~mL}$ of PCR buffer, homogenized and treated with proteinase $\mathrm{K}$ $(0.1 \mathrm{mg} / \mathrm{mL})$ for 60 minutes at $56^{\circ} \mathrm{C}$. The enzyme was inactivated with boiling water at $100^{\circ} \mathrm{C}$ for 10 minutes and maintained refrigerated at $-20^{\circ} \mathrm{C}$ until use.

DNA amplification was performed in two rounds of PCR. At first, Master Mix (MM) was prepared according to the amount of samples, using $36.35 \mu \mathrm{L}$ of DNAse free water, PCR Kit $[5 \mu \mathrm{L}$ Tris $\mathrm{HCl}+\mathrm{KCl} \mathrm{pH} 8.0 ; 3 \mu \mathrm{L} \quad \mathrm{MgCl}_{2}$; $0.25 \mu \mathrm{L}$ dNTPs (dATP, dCTP, dGTP, dTTP)], $1 \mu \mathrm{L}$ of each primer for gag gene, primer 1 (CAAGCAGCAGGAGGGAGAAGCTG) and primer 2 (TCCTACCCCCATAATT TGATCCAC) and $0.4 \mu \mathrm{L}$ of Taq DNA polymerase. Then, $47 \mu \mathrm{L}$ of the MM was transferred to each tube and $3 \mu \mathrm{L}$ of sample was added, including positive and negative controls. 
Samples were amplified (Mastercycler epgradientS eppendorf ${ }^{\circledR}$ realplex, Applied BioSystems, USA) with a four stage setup. At the first stage, five minutes at $94^{\circ} \mathrm{C}$, then a second stage of 35 cycles of the following sequence: $94^{\circ} \mathrm{C}$ for one minute (denaturation), $56^{\circ} \mathrm{C}$ for one minute (annealing), $72^{\circ} \mathrm{C}$ for $45 \mathrm{~s}$ (extension). In the third stage, the temperature was maintained at $72^{\circ} \mathrm{C}$ for seven minutes and in the last stage, amplified samples were maintained at $4^{\circ} \mathrm{C}$. For the second round, MM was again prepared with $38.35 \mu \mathrm{L}$ of DNAse free water, PCR kit, Taq DNA polymerase and primers

\section{(5'GTTCCAGCAACTGCAAACAGTAGCAAT}

G3') and 4

(5'ACCTTTCTGCTTCTTCATTTAATTTCCC3

') also for the gag gene. Then, $49 \mu \mathrm{L}$ of MM was transferred to tubes with $1 \mu \mathrm{L}$ of each product from the first round and again submitted to amplification. Following, PCR products were submitted to $2 \%$ agarose gel electrophoresis containing ethidium bromide $(2.5 \mu \mathrm{L}$ in $50 \mathrm{~mL})$ and buffer $(53.90 \mathrm{~g}$ of trizma base; $3.72 \mathrm{~g}$ of EDTA ethylenediaminetetraacetic acid; $27.5 \mathrm{~g}$ of boric acid) (Barlough et al, 1994; Saltarelli et al, 1990).

\section{RESULTS AND DISCUSSION}

In this study, in vitro culture of monolayers of fibroblastoid cells from sheep WJUC obtained at natural parturition through a simple method of explant culture in MEM, low glucose DMEM, M199, and RPMI-1640 was possible.

Cells began to migrate from explants to the plate surface after four days of culture (Fig. 1D) presenting similar growth in all four media used and subculture was possible after eight days, when monolayers reached $80 \%$ confluence.
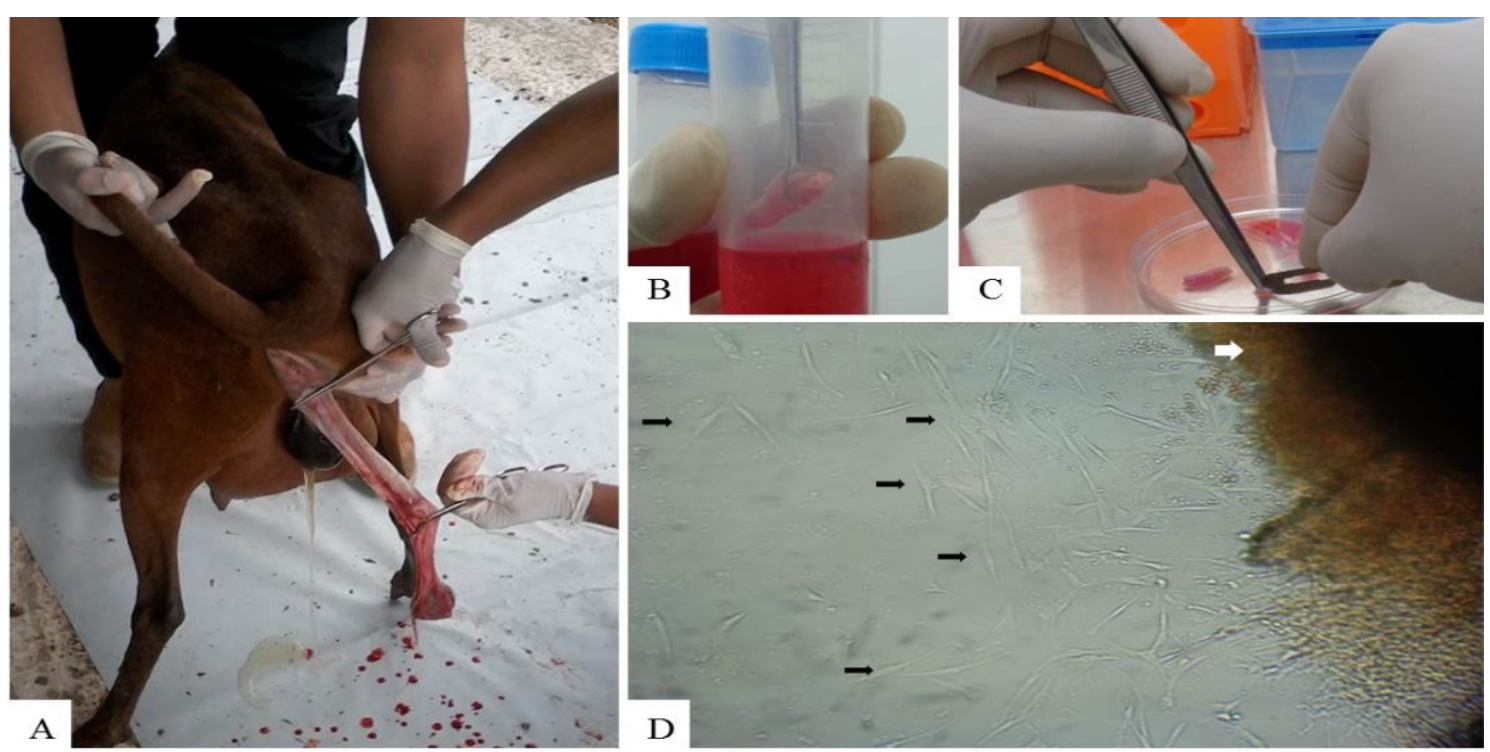

Figure 1. Collection of sheep umbilical cord at natural parturition (A), transport (B), explantation (C) and culture of primary cells collected from sheep Wharton's jelly of umbilical cord (white arrow: sheep WJUC explant border; black arrows: fusiform cells migrating to culture plate), P0, day 4, 100x.

Hendijani et al. (2014) reported with explant technique applied in human WJUC that cells began to migrate to plate surface 13 days after the beginning of culture and reached 80 to $100 \%$ confluence in 22 days. Caprine fibroblastoid cells are evident in the second culture day, reaching enough confluence for trypsinization after 10 days of culture (Moshrefi et al., 2010). Passeri et al. (2009) using enzymatic technique exposed umbilical cord tissue from mares to collagenase and reported the formation of individual fusiform cells with three to four days of culture and colonies in five days, performing subculture in seven days after initial seeding.

Although explant culture method requires a longer period to obtain cells from the collected tissue, this technique provides purer and less 
heterogenic cells with high proliferation rates (Salehinejad et al., 2012). In addition, the greater volume of cells in the umbilical cord and the easy manipulation, theoretically increase the number of cells that can be harvested, which provides a substantial number that can be obtained without the need for long-term culture or a vast ex vivo expansion (Iacono et al., 2015).
The presence of syncytia containing more than four nuclei was demonstrated in both in vitro infection by CAEV-Cork and MVV-K1514 in WJUC-derived sheep cells cultured in MEM, low glucose DMEM, M199 and RPMI-1640 (Fig. 2). In addition, sparse areas in monolayers, lytic effect and cellular death characterized by the presence of cells in suspension were observed.
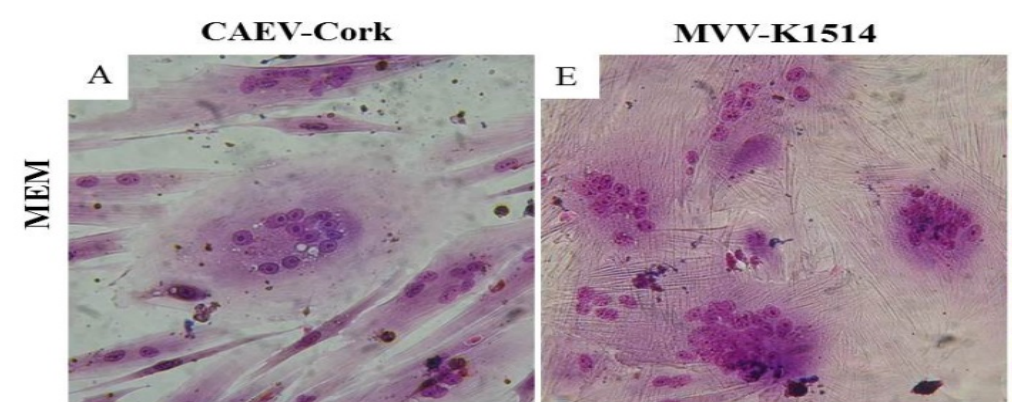

NEGATIVE CONTROL
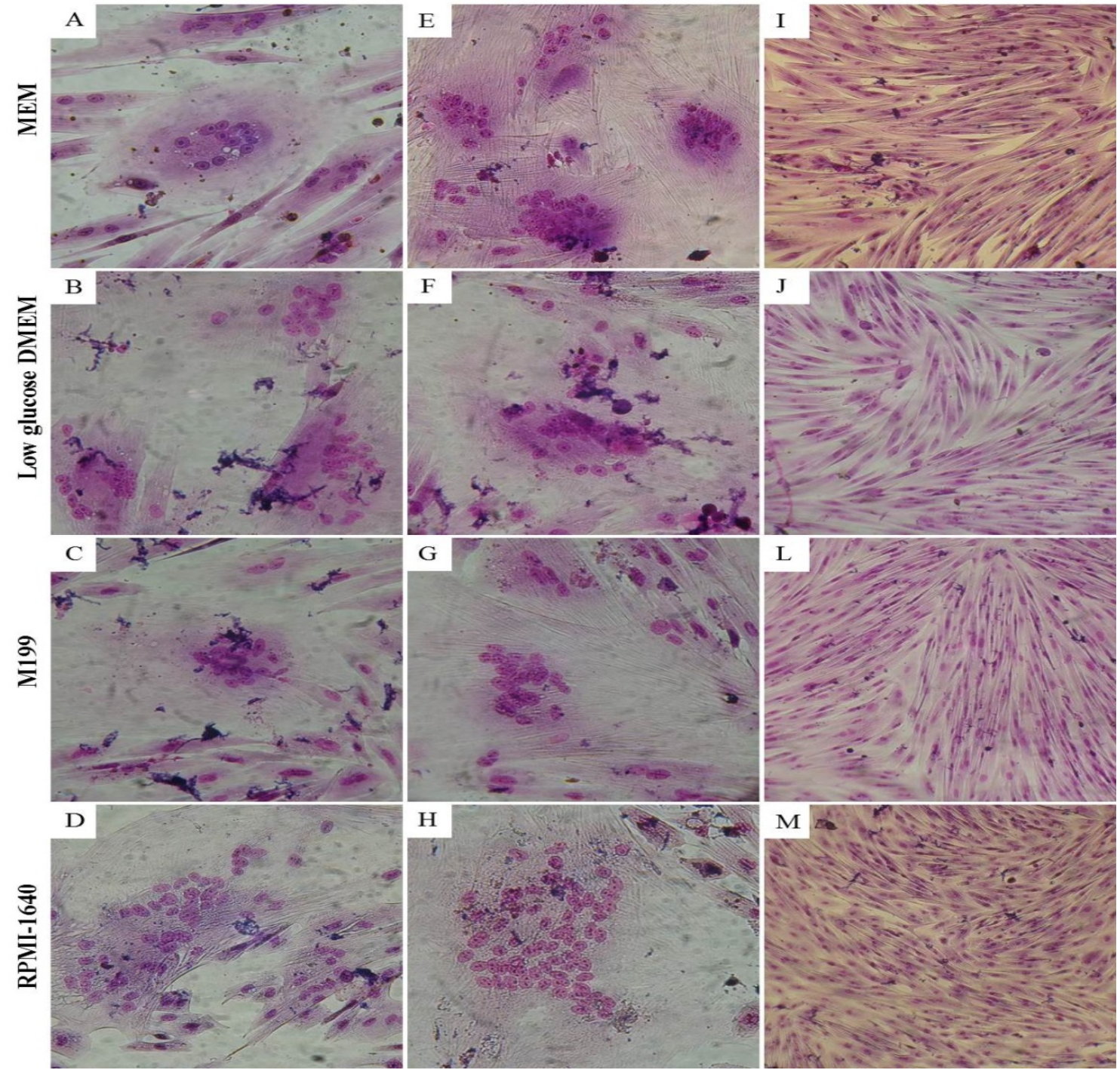

Figure 2. Cytopathic effect of CAEV-Cork (A, B, C, D) and MVV-K1514 (E, F, G, H) in WJUC-derived sheep cells cultured in MEM, low glucose DMEM, M199, and RPMI-1640. P2, 400x. Negative control of sheep cells from WJUC (I, J, L, M). P2, 100x, stained with May Grunwald Giemsa.

Syncytial formation caused by in vitro inoculation with CAEV have been previously described in GSM, which is similar to what is caused by MVV. In this case, cells fuse as a result of direct interaction with input virus and this behavior is termed fusion from without, which occurs before viral replication (Ellis et al., 1985). 
In addition to the presence of syncytia, lytic effect was also observed with the destruction of cellular monolayers and the most intense result was caused by CAEV-Cork in WJUC-derived sheep cells cultured in RPMI-1640 with the destruction of approximately $80 \%$ of monolayers three days post infection (Fig. 3). All other treatments presented lysis, however both strains presented syncytial formation as the predominant cytopathic effect having minor lytic character until the seven days post infection.
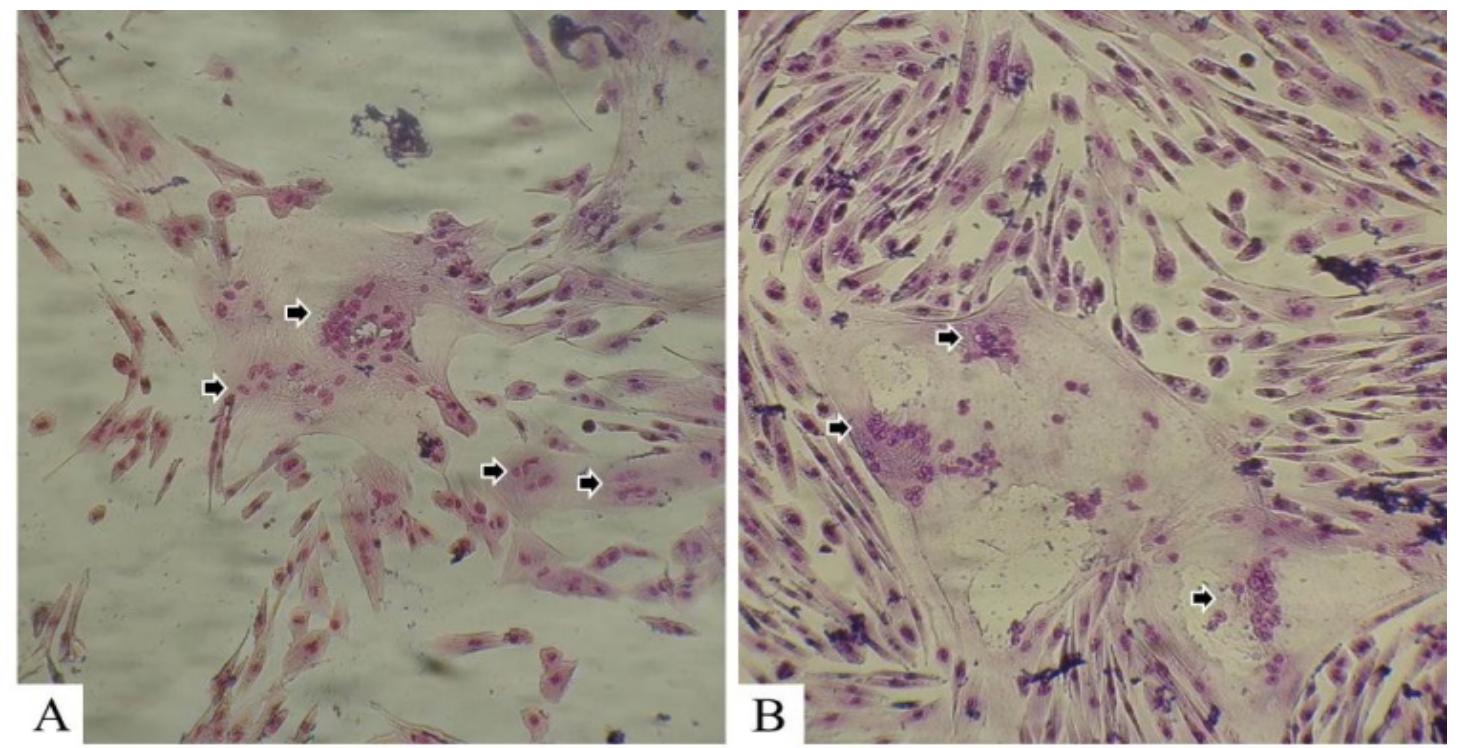

Figure 3. Cytopathic effect in WJUC-derived sheep cells cultured in RPMI-1640 after three days post infection. (A) Infection with CAEV-Cork generating intense lysis in monolayer. (B) Infection with MVVK1514 in initial phase of lysis in monolayer of cells. Arrows: Syncytia. 100x. May Grunwald Giemsa.

Artificially infected sheep cells from WJUC hosted proviral genome as detected by nestedPCR. This was confirmed with the visualization of an $187 \mathrm{pb}$ product amplified from the targeted- sequence of proviral DNA (Figure 4), which occurred in both strains, CAEV-Cork and MVV$\mathrm{K} 1514$, producing infectious viruses to the culture media.

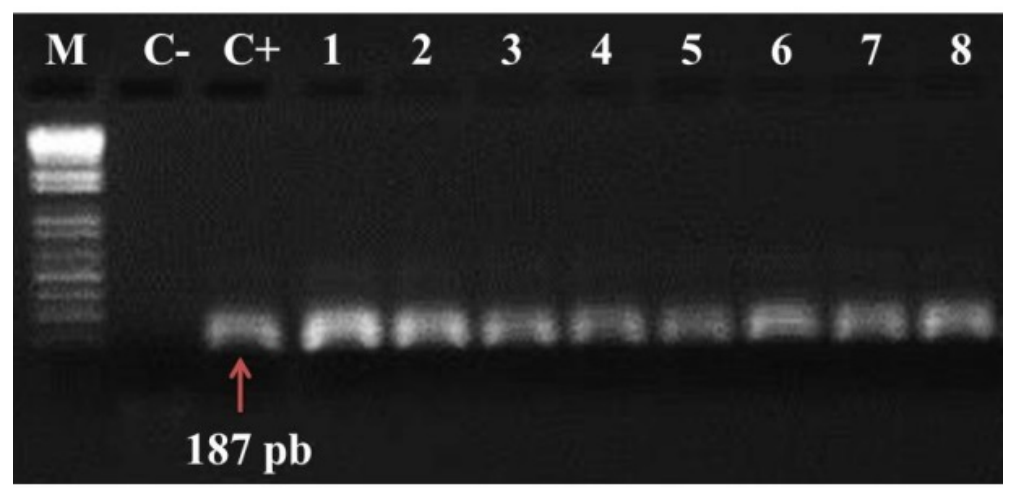

Figure 4. Amplification products of $187 \mathrm{pb}$ compatible with the targeted-sequence of CAEV proviral DNA in 2\% agarose gel stained with ethidium bromide. M (DNA ladder 100pb Marker); C- (negative control); C+ (positive control); 1, 2, 3, and 4 (positive samples from supernatant of umbilical cord sheep cells infected with CAEV-Cork and cultured in MEM, low glucose DMEM, M199 and RPMI-1640, respectively); 5, 6, 7, and 8 (positive samples from the supernatant of umbilical cord sheep cells infected with MVV-K1514 and cultured in MEM, low glucose DMEM, M199, and RPMI-1640, respectively). 
To demonstrate that the released viral proteins of CAEV-Cork and MVV-K1514 were newly mounted and infectious, culture media used in infected sheep cells from WJUC were collected in the 21 day period and used in the viral titration essay with GSM, estimating the approximate amount of infectious viral particles.

Different titers were observed for the same viral strains inoculated in WJUC-derived sheep cells cultured in different media and CAEV-Cork in RPMI-1640 medium was the most elevated $\left(10^{5.7}\right.$ $\left.\mathrm{TCID}_{50} / \mathrm{mL}\right)$, followed by MVV-K1514 in M199 $\left(10^{4.7} \mathrm{TCID}_{50} / \mathrm{mL}\right)$. Inferior titers were obtained when low glucose DMEM medium was used in maintenance with titers of $10^{4.0} \mathrm{TCID}_{50} / \mathrm{mL}$ of CAEV-Cork strain and $10^{3.5} \mathrm{TCID}_{50} / \mathrm{mL}$ of MVV-K1514 strain.

Comparing viral titers obtained in each medium revealed that CAEV-Cork were more elevated than those obtained with MVV-K1514 infection in every case (Tab. 1)
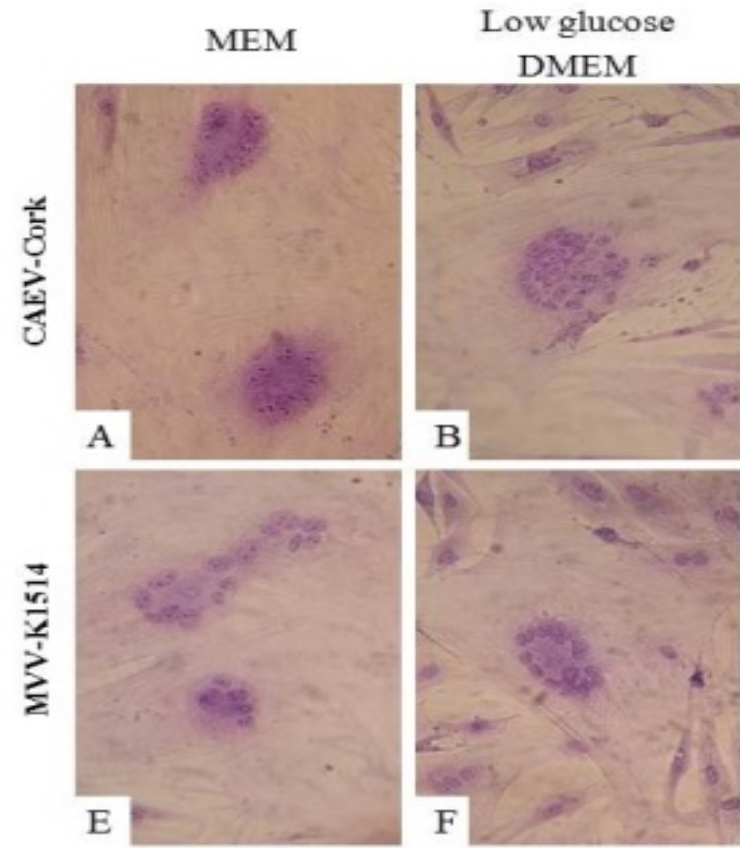

Figure 5. Cytopathic effect in GSM cells. Viral titration of CAEV-Cork (A, B, C, D) and MVV-1514 (E, $\mathrm{F}, \mathrm{G}, \mathrm{H})$ replicated in sheep cells from WJUC in different media. Dilution $10^{-3}, 400 \mathrm{x}$, Crystal Violet staining.

Supernatants of GSM cells infected with CAEVCork and MVV-1514 were used as standards and viral titration was performed. These results were similar to the titers obtained with the infected
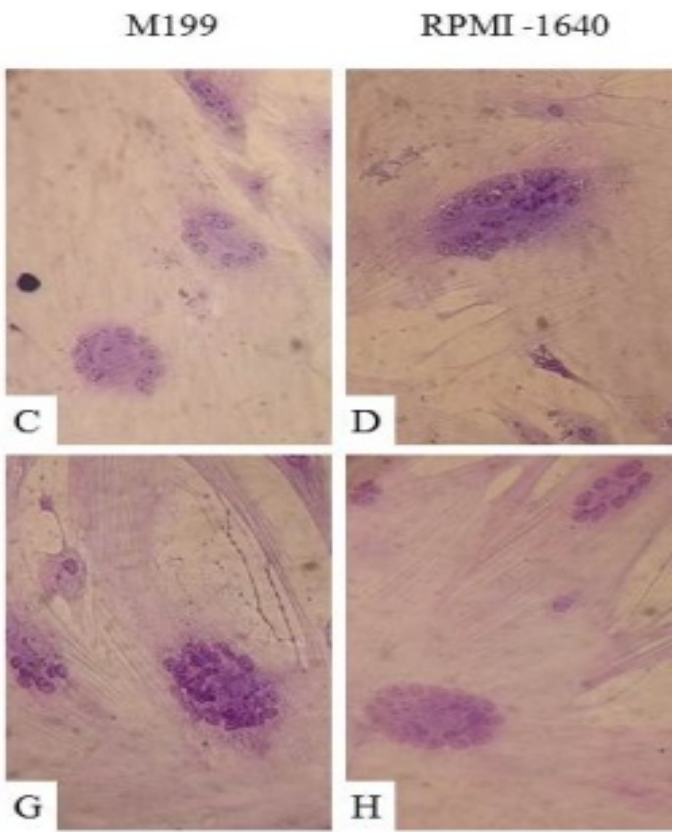

Table 1. Titration of CAEV-Cork and MVVK1514 replicated in umbilical cord sheep cells cultured in MEM, low glucose DMEM, M199, and RPMI-1640

\begin{tabular}{|c|c|c|}
\hline \multirow{2}{*}{$\begin{array}{l}\text { Supernatant } \\
\text { medium }\end{array}$} & \multicolumn{2}{|c|}{$\mathrm{TCID}_{50} / \mathrm{mL}$ titers } \\
\hline & CAEV-Cork & MVV-K1514 \\
\hline MEM & $10^{5.5}$ & $10^{4.3}$ \\
\hline $\begin{array}{l}\text { Low glucose } \\
\text { DMEM }\end{array}$ & $10^{4.0}$ & $10^{3.5}$ \\
\hline M199 & $10^{5.0}$ & $10^{4.7}$ \\
\hline RPMI-1640 & $10^{5.7}$ & $10^{3.5}$ \\
\hline
\end{tabular}

According to Ellis et al. (1985), GSM cells form syncytia only when in contact with intact viral particles, excluding the possibility that this cytopathic effect occurs due to intracellular precursors of a fusion protein or cellular products contained in the medium. This way, the cytopathic effect visualized in monolayer of GSM cells reported in this study demonstrates the presence of intact viral particles in supernatant of infected sheep cells from WJUC (Figure 5)

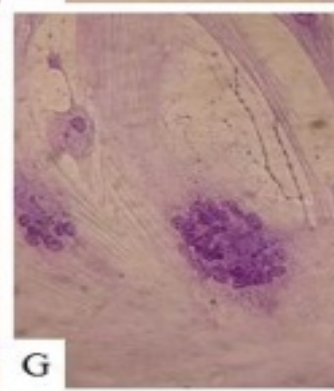


Table 2. Titration of CAEV-Cork and MVV-

K1514 replicated in GSM cells

\begin{tabular}{cc}
$\begin{array}{c}\text { Virus replicated in GSM } \\
\text { cells }\end{array}$ & TCID $_{50} / \mathrm{mL}_{\text {titer }}$ \\
\hline CAEV-Cork & $10^{4.5}$ \\
MVV-K1514 & $10^{4.7}$ \\
\hline
\end{tabular}

Demonstrating the in vitro permissiveness of sheep cells from WJUC is an important result that adds knowledge, along with other researches, aiming to understand the mechanism of vertical pre-natal transmission of these lentiviruses to the fetus, which have been reported (Cutlip et al., 1981; Brodie et al., 1994). However, the exact pathway that this transmission occurs is not yet fully understood (Cortez-Romero et al., 2013).

In addition, obtaining satisfactory viral titers for the production of antigens for diagnostic applications aggregate value to sheep umbilical cords, which is a tissue routinely discarded in sheep farming.

\section{CONCLUSION}

Cells from sheep WJUC obtained at natural parturition are permissive to infection by CAEVCork and MVV-K1514 and present characteristic cytopathic effect. In addition, these cells, when infected, produce replication when using MEM, low glucose DMEM, M199, and RPMI-1640 as culture media and present a potential for largescale antigen production in all of these. Additionally, sheep umbilical cord is a viable alternative to avoid using fetus and euthanasia in young animals to obtain cells for in vitro replication of SRLVs.

\section{ACKNOWLEDGMENTS}

The authors would like to thank CNPq (Universal proc. 487425/2012-0) and AUXPEPROEX 533/2014 for the financial support, EMBRAPA Caprinos e Ovinos for the technical support and to CAPES for granting the doctoral scholarship.

\section{REFERENCES}

BA'NKOWSKI, E.; ROMANOWICZ, L.; JAWORSKI, S. Collagen of the umbilical cord and its alteration in EPH-gestosis. J. Perinat. Med., v.21, p.491-498, 1993.
BARLOUGH, J.; EAST, N.; ROWE, J.D. et al. Double-nested polymerase chain reaction for detection of caprine arthritis encephalitis virus proviral DNA in blood, milk, and tissues of infected goats. J. Virol. Methods, v.50, p.101113, 1994.

BRODIE, S.J.; CONCHA-BERMEJILLO, A.; KÖENIG, G. et al. Maternal factors associated with prenatal transmission of ovine lentivirus. $J$. Infect. Dis., v.169, p.653-657, 1994.

CAPRINE arthritis/encephalitis \& Maedi-visna. OIE Terrestrial manual. Chapter 2.7.3/4. 2008. p.983-991. Available in: <http://www.oie.int/ fileadmin/Home/eng/Health_standards/tahm/2.07 .03-04_CAE_MV.pdf $\geq$ : Accessed in: 1 Fev. 2016.

CARDOSO, T.C.; FERRARI, H.F.; GARCIA, A.F. et al. Isolation and characterization of Wharton's jelly-derived multipotent mesenchymal stromal cells obtained from bovine umbilical cord and maintained in a defined serum-free three-dimensional system. BMC Biotechnol., v.12, p.1-12, $2012 \mathrm{a}$.

CARDOSO, T.C.; NOVAIS, J.B.; ANTELLO, T.F. et al. Susceptibility of neuron-like cells derived from bovine Wharton's jelly to bovine herpesvirus type 5 infections. BMC Vet. Res., v.8, p.1-11, 2012b.

CORTEZ-ROMERO, C.; PELLERIN, J.L.; ALIAL-AHMAD, M.Z. et al. The risk of small ruminant lentivirus (SRLV) transmission with reproductive biotechnologies: State-of-the-art review. Theriogenology, v.79, p.1-9, 2013.

CUTLIP, R.C.; LEHMKUHL, H.D.; JACKSON, T.A. Intrauterine transmission of ovine progressive pneumonia virus. Am. J. Vet. Res., v.42, p.1795-1797, 1981.

ELLIS, T.M.; WILCOX, G.E.; ROBINSON, W.F. Characteristics of cell fusion induced by a caprine retrovirus. Arch. Virol., v.86, p.263-273, 1985.

HENDIJANI, F.; SADEGHI-ALIABADI, H.; JAVANMARD, S.H. Comparison of human mesenchymal stem cells isolated by explant culture method from entire umbilical cord and Wharton's jelly matrix. Cell Tissue Bank, v.15, p.555-565, 2014. 
IACONO, E.; ROSSI, B.; MERLO, B. Stem cells from foetal adnexa and fluid in domestic animals: an update on their features and clinical application. Reprod. Dom. Anim., v.50, p.353364, 2015.

MINGUIJÓN, E.; REINA R.; PÉREZ, M. et al. Small ruminant lentivirus infections and diseases. Vet. Microbiol., v.181, p.75-89, 2015.

MOSHREFI, M.; BABAEI, H.; NEMATOLLAHI-MAHANI, S.N. Isolation and characterization of mesenchymal cells isolated from caprine umbilical cord matrix. Anim. Reprod., v.7, p.367-372, 2010.

PASSERI, S.; NOCCHI, F.; LAMANNA, R. et $a l$. Isolation and expansion of equine umbilical cord-derived matrix cells (EUCMCs). Cell Bio. Internat., v.33, p.100-105, 2009.
SALEHINEJAD, P.; ALITHEEN, N.B.; ALI, A.M. et al. Comparison of different methods for the isolation of mesenchymal stem cells from human umbilical cord Wharton's jelly. In Vitro Cell. Dev. Biol. Anim., v.48, p.75-83, 2012.

SALTARELLI, M.; QUERAT, G.; KONINGS, D.A. et al. Nucleotide sequence and transcriptional analysis of molecular clones of CAEV which generate infectious virus. Virology, v.179, p.347-364, 1990.

VITA, B.; CAMPOS, L.L.; LISTONI, A.J. et al. Anexos fetais: uma fonte alternativa de célulastronco mesenquimais para a medicina veterinária equina. Vet. Zootec., v.1, p.8-22, 2012. 